\title{
A Selective Flotation-Spectrophotometric Method for the Determination of Nickel using Dimethylglyoxime
}

\author{
Hamid Hashemi-Moghaddam* \\ Department of Chemistry, Islamic Azad University Damghan Branch, \\ PO Box 36716-39998, Damghan, Iran
}

\begin{abstract}
Um método simples e seletivo para a separação e pré-concentração de níquel foi desenvolvido. O método é baseado na flotação de um complexo de Ni e dimetilglioxima (DMG) na interface de uma solução aquosa com $n$-hexano. O complexo Ni-DMG foi separado e determinado por espectrofotometria. A flotação quantitativa do complexo foi possível no intervalo de pH de 9-12. O método é simples e livre da interferência de todos os cátions e ânions e apresenta um grande intervalo linear. O procedimento foi aplicado com sucesso na determinação de traços de níquel em águas de poços e águas residuais de um processo de eletrodeposição. A exatidão do método foi avaliada usando material de referência certificado (NIST 864) e enriquecendo as amostras com diferentes quantidades de $\mathrm{Ni}^{2+}$.
\end{abstract}

A simple and selective method for separation and preconcentration of nickel has been developed. The method is based on the flotation of a complex of $\mathrm{Ni}$ and dimethylglyoxime (DMG) at the aqueous solution- $n$-hexane interface. The complex was separated and Ni determined spectrophotometrically by DMG after addition of oxidizing agent. The quantitative flotation of the complex was possible in the $\mathrm{pH}$ range of 9-12. The method is simple and free from the interference of all cations and anions and has a wide linear range. The procedure was successfully applied to the determination of trace amounts of nickel in well water and waste water in coating plant. The method's accuracy was investigated by using standard reference materials alloys (NIST 864) and by spiking the samples with different amounts of $\mathrm{Ni}^{2+}$.

Keywords: flotation, spectrophotometry, dimethylglyoxime, nickel

\section{Introduction}

Nickel is an important constituent of several steel alloys. Its determination is required to control both raw material and industrial products. ${ }^{1}$ In addition it is readily encountered in the environment, which enters from land-based resources, such as oxidic and sulfide ores or industrial sources, such as spent catalysts, alloy scrap, sludge, dust, and wastewater. ${ }^{2}$

Dimethylglyoxime (DMG) is widely used and for the spectrophotometric determination of nickel ${ }^{3,4}$ it has also been used for separation and preconcentration of $\mathrm{Ni}$ by liquid-liquid extraction ${ }^{5}$ or solid phase extraction ${ }^{6-8}$ but all of these separation methods suffer from lack of selectivity. For example, metal ions such as $\mathrm{Ni}(\mathrm{II}), \mathrm{Pb}(\mathrm{II}), \mathrm{Mn}(\mathrm{II})$, $\mathrm{Bi}(\mathrm{III}), \mathrm{Co}(\mathrm{II}), \mathrm{Cd}(\mathrm{II}), \mathrm{Zn}$ (II), and $\mathrm{Fe}(\mathrm{II})$ could interfere at concentrations higher than $5 \mathrm{mg} \mathrm{L}^{-1}$ in solid phase extraction of $\mathrm{Ni}^{2+}$ using DMG as a complexing agent. ${ }^{8}$

\footnotetext{
*e-mail: h.hashemimoghadam@damghaniau.ac.ir
}

This paper deals with a selective and simple method for separation and preconcentration of Ni with DMG.

Flotation spectrophotometry allows one to preconcentrate the trace elements in various materials. ${ }^{9-24}$ Primary investigations showed that the none of two usual complexes of $\mathrm{Ni}$ and DMG could not float completely in interface of liquid and organic phase due to solubility in water and organic phase of $\mathrm{Ni}(\mathrm{Dm})_{3}{ }^{2-}$ and $\mathrm{Ni}(\mathrm{HDm})_{2}$, respectively. Thus a different complex of $\mathrm{Ni}$ and DMG was studied. As it observed, in more basic pHs, a different complex could be formed that is floated in interfaces of two phases. This complex is formed very fast and metal ions (e.g., $\mathrm{Fe}^{2+}, \mathrm{Co}^{2+}$ and $\mathrm{Cu}^{2+}$ ) which form colored, water-soluble complexes with dimethylglyoxime do not interfere in this condition. Simple spectrophotometric determination of trace amounts of $\mathrm{Ni}$ in complex environmental samples by DMG could be possible after preconcentration and separation of $\mathrm{Ni}(\mathrm{II})$ with this method. 


\section{Experimental}

\section{Materials}

The solutions were prepared with freshly deionized water and chemicals of analytical reagent grade. The $1.000 \mathrm{~g} \mathrm{~L}^{-1}$ $\mathrm{Ni}$ standard stock solution was prepared by dissolving $6.7300 \mathrm{~g}\left(\mathrm{NH}_{4}\right)_{2} \mathrm{Ni}\left(\mathrm{SO}_{4}\right)_{2} \cdot 6 \mathrm{H}_{2} \mathrm{O}$ (Merck, Germany) in water containing $2 \mathrm{~mL}$ of concentrated $\mathrm{H}_{2} \mathrm{SO}_{4}$ and completing the volume to one liter with water. The $2 \%(\mathrm{~m} / \mathrm{v})$ dimethylglyoxime solution was prepared by dissolution of an appropriate amount of reagent in $250 \mathrm{~mL}$ of a $2.0 \mathrm{~mol} \mathrm{~L}^{-1}$ $\mathrm{NaOH}$ solution. Potassium persulfate, $4 \%(\mathrm{~m} / \mathrm{v})$ solution, freshly was prepared. Sodium borate- boric acid buffer ( $\mathrm{pH}$ 10.0). This solution was prepared by dissolving $12.78 \mathrm{~g}$ of sodium borate (Merck) in $100 \mathrm{~mL}$ of water, followed by the addition and dissolution of $6.18 \mathrm{~g}$ of boric acid (Merck) and was diluted to $1000 \mathrm{~mL}$.

The standard reference material with certified values was the NIST 864 (New York, USA) Inconel 600. The materials were dissolved in concentrated $\mathrm{HCl}$ and $\mathrm{HNO}_{3}$ acids. ${ }^{25}$

\section{Sample collection}

Wastewater samples were collected from a nickelchrome electroplating plant in Damghan, Iran. The samples were put in plastic containers initially rinsed three times with the wastewater.

\section{Sample preparation}

The waste water and well water samples were filtered through a $0.45 \mu \mathrm{m}$ membrane filter paper. An aliquot of the filtered sample $(10 \mathrm{~mL})$ was put into a $250 \mathrm{~mL}$ conical flask and digested with $5 \mathrm{~mL}$ mixture of concentrated nitric acid $(65 \%, \mathrm{v} / \mathrm{v})$ and perchloric acid $(70 \%, \mathrm{v} / \mathrm{v})$. When digestion was complete, $10 \mathrm{~mL}$ of $0.5 \mathrm{~mol} \mathrm{~L}^{-1} \mathrm{HCl}$ was added to redissolve the residue and the resultant solution filtered into a $50 \mathrm{~mL}$ volumetric flask.

\section{Apparatus}

Cary 100 (Varian, Australia) spectrophotometer with a quartz cell (10.0 mm optical path) was employed for nickel determinations. A pH meter, Metrohm744A, was used for $\mathrm{pH}$ measurements.

\section{Procedure}

To the solution containing not more than $50 \mu \mathrm{g}$ of $\mathrm{Ni}, 5 \mathrm{~mL}$ of $0.02 \mathrm{~mol} \mathrm{~L}^{-1}$ EDTA solution and $10 \mathrm{~mL}$ of boric acid/sodium borate buffer was added. The solution was transferred to a $250 \mathrm{~mL}$ separating funnel; then $2 \mathrm{~mL}$ dimethylglyoxime $(2 \%, \mathrm{~m} / \mathrm{v})$ and $10 \mathrm{~mL} n$-hexane were added sequentially. The funnel was stoppered, vigorously shaken for $2 \mathrm{~min}$, then left to rest for a few minutes. As soon as the floating layer had settled at the organic interface, both the upper organic and lower aqueous layers were discarded by slowly opening the cock of the funnel. Then, for dissolving the floated complex, which was completely adhering to the inner walls of the funnel, $4 \mathrm{~mL} 2 \%(\mathrm{~m} / \mathrm{v})$ of DMG, $1 \mathrm{~mL}$ of $4 \%(\mathrm{~m} / \mathrm{v})$ persulfate solution and $2.5 \mathrm{~mL}$ of concentrated $\mathrm{NH}_{3}$ solution were added successively. The obtained solution was quantitatively transferred into a $25 \mathrm{~mL}$ flask and diluted to the mark with water. Finally, the absorbance at $445 \mathrm{~nm}$ against water was measured.

\section{Results and Discussion}

The reaction between $\mathrm{Ni}$ and dimethylglyoxime is a well established process. DMG reacts with $\mathrm{Ni}$ ions in a neutral or ammoniacal medium to form a pink, flocculent precipitate which has been the basis of the well known gravimetric method for determining nickel. The nickel dimethylglyoximate chelate is soluble in $\mathrm{CHCI}_{3}$ and other non polar organic solvents. The extraction of $\mathrm{Ni}(\mathrm{HDm})_{2}$ is primarily important in the separation of nickel, but relatively large quantities of nickel have been determined by means of the pale yellow chloroform solution of $\mathrm{Ni}(\mathrm{HDm})_{2}$. Also in an alkaline medium and in the presence of oxidants, nickel forms a brown-red, water soluble DMGcomplex, which is the basis of the very popular method for determining nickel. In this complex, nickel is in the IV oxidation state, and the anionic complex has the formula $\mathrm{Ni}(\mathrm{Dm})_{3}{ }^{2-} \cdot{ }^{3}$ Primary investigation showed that any of each two complexes could not float completely in the interface of liquid and organic phase because of solubility in water and organic phase of $\mathrm{Ni}(\mathrm{Dm})_{3}{ }^{2-}$ and $\mathrm{Ni}(\mathrm{HDm})_{2}$, respectively. Thus a different complex of Ni and DMG was studied. As it was observed, in more basic pH and with DMG, which dissolved in $\mathrm{NaOH}$ solution a different complex could be formed that is floated in interfaces of two phases.

$$
\begin{gathered}
\mathrm{Ni}^{2+}+2 \mathrm{DH}_{2} \rightarrow \mathrm{Ni}(\mathrm{DH})_{2}+2 \mathrm{H}^{+} \\
\mathrm{Ni}(\mathrm{DH})_{2}+2 \mathrm{OH}^{-} \rightarrow\left[\mathrm{NiD}_{2}\right]^{2-}+2 \mathrm{H}_{2} \mathrm{O}(\text { in alkaline solution }) \\
\mathrm{Ni}^{2+}+2 \mathrm{DH}_{2}+2 \mathrm{OH}^{-} \rightarrow\left[\mathrm{NiD}_{2}\right]^{2-}+2 \mathrm{H}^{+}+2 \mathrm{H}_{2} \mathrm{O}
\end{gathered}
$$

Though the spectroscopic evidence indicated the presence of various nickel-DMG complexes with different ratios of metal to ligand (1:2 and 1:4) in solution, the 
difficulties still encountered in the identification of a "metastable" complex are not early understood. ${ }^{26}$

The various parameters such as $\mathrm{pH}$, shaking times and the concentration of the ligand, which influence the flotation and spectrophotometric determination of nickel, were optimized.

\section{Optimization}

The effect of the $\mathrm{pH}$ on the flotation of the complex was investigated by varying the $\mathrm{pH}$ of $\mathrm{Ni}(\mathrm{II})$ solution $\left(1.7 \times 10^{-6} \mathrm{~mol} \mathrm{~L}^{-1}\right)$ in the range from 4 to 12 before the addition of the organic phase. The results in Figure 1, indicates that the maximum absorbance occurs at $\mathrm{pH}$ above 9 . The decrease in absorbance at lower $\mathrm{pH}$ values was attributed to the protonation of the weakly basic coordination group of ligand and also because in neutral $\mathrm{pH}$ $\mathrm{Ni}(\mathrm{HDm})_{2}$ could be formed, which is dissolved somewhat in $n$-hexane. In the subsequent work, pH 10 was selected.

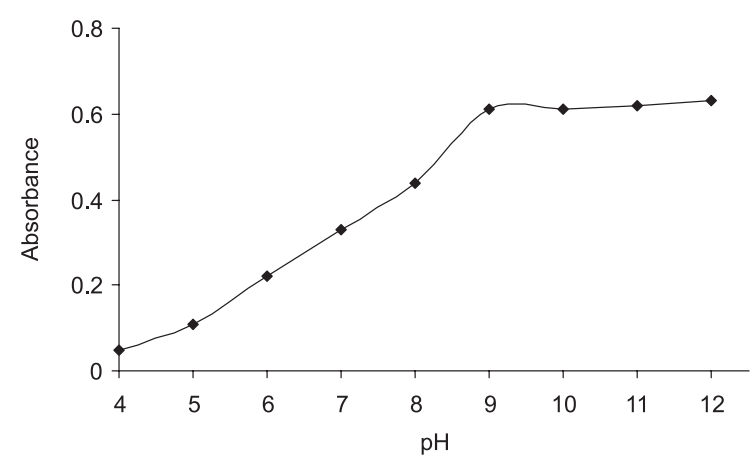

Figure 1. Effect of $\mathrm{pH}$ on the flotation process at the conditions where: $[\mathrm{Ni}(\mathrm{II})]=4 \times 10^{-6} \mathrm{~mol} \mathrm{~L}^{-1}$ and $[\mathrm{DMG}]=4 \times 10^{-4} \mathrm{~mol} \mathrm{~L}^{-1}$.

Fast formation of Ni-DMG complex and no solubility of complex in $n$-hexane are depending on the kind of DMG solvent. If DMG is dissolved in ethanol, efficiency of flotation would be low but flotation efficiency increase in more basic solvents because of increasing polarity of Ni-DMG complex. The effect of the agitation time on the flotation was studied by varying the shaking time between 10 and $180 \mathrm{~s}$. The result of the investigation indicates that the time of $60 \mathrm{~s}$ is sufficient for the quantitative formation and flotation of the complex.

The effect of the DMG concentration on the flotation of the complex was studied over the concentration range of $0.1 \times 10^{-5}$ to $1 \times 10^{-3} \mathrm{~mol} \mathrm{~L}^{-1}$. As shown in Figure 2, maximum absorbance occurs to DMG concentrations above $2 \times 10^{-4} \mathrm{~mol} \mathrm{~L}^{-1}$. Since by increasing the concentration of $\mathrm{Ni}(\mathrm{II})$ ions, a greater amount of DMG was required, a solution with $4 \times 10^{-4} \mathrm{~mol} \mathrm{~L}^{-1} \mathrm{DMG}$ was chosen for further investigations.

Flotation of the complex was investigated with several organic solvents. It was found that the absorbance depends

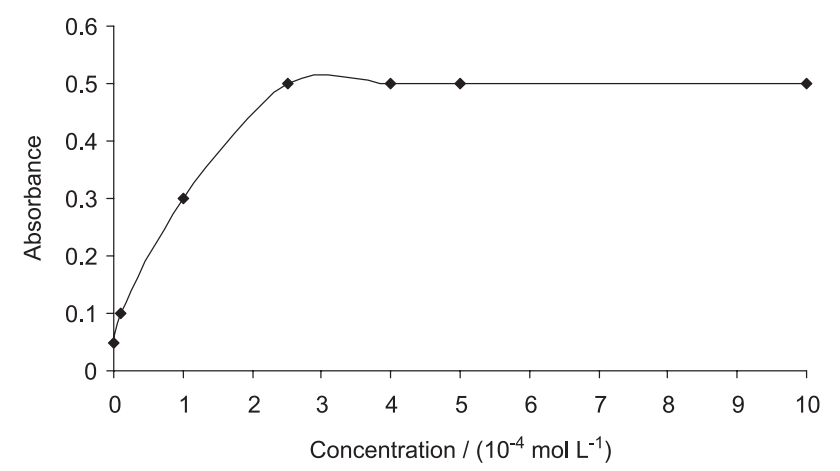

Figure 2. Effect of DMG concentration on the determination of $\mathrm{Ni}(\mathrm{II})$ at the conditions where: $\mathrm{pH}=10$ and $[\mathrm{Ni}]=4 \times 10^{-6} \mathrm{~mol} \mathrm{~L}^{-1}$.

on the solvent. For example, at the optimum conditions, the absorbance values for the flotation of $4 \times 10^{-6} \mathrm{~mol} \mathrm{~L}^{-1}$ $\mathrm{Ni}(\mathrm{II})$ with cyclohexane, $n$-heptane, and $n$-hexane were $0.438,0.462$ and 0.486 , respectively. In addition, quicker separation between the phases was observed using $n$-hexane. Thus, it was chosen for the further investigations. Furthermore, the complex is dissolved somewhat in solvent such as, toluene, xylene and chloroform.

A possible concern was whether a high enrichment factor could be realized. This was investigated by carrying the flotation processes and varying the volume of the aqueous solution between 20 and $250 \mathrm{~mL}$, while maintaining the amounts of nickel and the organic-phase constant. It was found that the flotation process was quantitative over the range of $20-150 \mathrm{~mL}$ of the aqueous phase. A higher volume, however, resulted in a decrease in the efficiency of the flotation process.

\section{Analytical performance}

Under the optimum conditions, a linear calibration curve was obtained for $\mathrm{Ni}$ (II) over the range from $1 \times 10^{-6}$ to $2 \times 10^{-5} \mathrm{~mol} \mathrm{~L}^{-1}$, with the correlation coefficient $(\mathrm{r})$ of 0.9973 $\left(\mathrm{A}=5.42 \times 10^{4}[\mathrm{Ni}]-0.0463\right.$, where $\mathrm{A}$ is the absorbance and $[\mathrm{Ni}]$ is the concentration in $\mathrm{mol} \mathrm{L}^{-1}$ ). The apparent molar absorptivity at $445 \mathrm{~nm}$ was $5.42 \times 10^{4} \mathrm{~L} \mathrm{~mol}^{-1} \mathrm{~cm}^{-1}$ for a $100 \mathrm{~mL}$ aliquot of the aqueous phase and a path length of $1 \mathrm{~cm}$. The relative standard deviation $(\mathrm{n}=6)$ at $4 \times 10^{-6} \mathrm{~mol} \mathrm{~L}^{-1}$ of $\mathrm{Ni}^{2+}$ for a $100 \mathrm{~mL}$ sampling volume was $2.7 \%$ and the detection optical limit is defined as the sample concentration giving a signal equal to the blank average signal ( 25 blank) plus three times the standard deviation of the blanks was found to be $1.7 \times 10^{-7} \mathrm{~mol} \mathrm{~L}^{-1}$.

\section{Interferences}

The most significant interferences for the nickel determination with DMG are $\mathrm{Cu}^{2+}, \mathrm{Co}^{2+}$ and $\mathrm{Fe}^{2+}$ that 
produce stable complexes with the organic reagent. But, for example, although the copper complex of dimethylglyoxime is certainly more stable thermodynamically than the nickel complex, the latter is far more insoluble because of the special features of the packing of discrete molecules in the crystal lattice which provides strong axial $\mathrm{Ni}-\mathrm{Ni}$ bonds through the lattice. ${ }^{26}$ So, in this flotation method, complexes of $\mathrm{Cu}^{2+}, \mathrm{Co}^{2+}$ and $\mathrm{Fe}^{2+}$ with DMG could not be floated in interface of two phases and have not any interference in the determination of $\mathrm{Ni}^{2+}$. In the case of palladium, it produces a yellow precipitate from weak acid solution however it could be floated partially but this yellow complex could not interfere in flotation spectrophotometric determination of $\mathrm{Ni}$ by dimethylglyoxime. In addition, usually the concentration of Pd is very low in environmental samples. Formation of insoluble compounds was prevented in the alkaline medium by adding $5 \mathrm{~mL}$ of $0.02 \mathrm{~mol} \mathrm{~L}^{-1}$ EDTA solution.

\section{Application}

To validate the methodology, the proposed method was applied to different environmental samples for $\mathrm{Ni}$ determination. The wastewater was collected from an electroplating plant. Along with the samples, several known amounts of $\mathrm{Ni}$ (II) were spiked to examine the reliability of the method (Table 1).

Furthermore, the accuracy of the method was investigated by analysis of standard reference materials alloys (NIST 864) by flotation spectrophotometry method. The certified Ni was $73.10 \%$, and Ni found was $73.04 \pm 0.08 \%$, in good agreement with the certified value at the $95 \%$ confidence level.

Table 1. Determination of nickel in real samples

\begin{tabular}{lccc}
\hline Sample & $\begin{array}{c}\mathrm{Ni}(\mathrm{II}) \text { Added } \\
\left(\mu \mathrm{g} \mathrm{mL}^{-1}\right)\end{array}$ & $\begin{array}{c}\mathrm{Ni}(\mathrm{II}) \mathrm{Measured}^{\mathrm{a}} \\
\left(\mu \mathrm{g} \mathrm{mL}^{-1}\right)\end{array}$ & Recovery \\
\hline Waste water & 0 & $0.112 \pm 0.024$ & - \\
& 0.100 & $0.214 \pm 0.045$ & $101 \%$ \\
& 0.200 & $0.321 \pm 0.034$ & $103 \%$ \\
\hline Well water & N.D. ${ }^{\mathrm{b}}$ & N.D. & - \\
& 0.100 & $0.094 \pm 0.034$ & $94 \%$ \\
& 0.200 & $0.193 \pm 0.027$ & $96 \%$ \\
\hline
\end{tabular}

aThe results are reported as the average value from five sample measurements. ${ }^{\mathrm{b}}$ Not detected.

\section{Conclusion}

In a different way, a complex of Ni with dimethylglyoxime was formed in order to separate and preconcentrate $\mathrm{Ni}$ ions by flotation spectrophotometric method. High tolerance to interference matrix ions in different samples, selectivity and a low cost are the main benefits of the presented method. Low detection limit and high tolerance to interferences from the matrix allow application of the proposed procedure for Ni determination in a large range of samples. Besides of presenting an analytical method for nickel determination, preparation and separation of new complexes of $\mathrm{Ni}$ and DMG is possible with this method.

Though the spectroscopic evidence indicated the presence of various nickel-DMG complexes with different ratios of metal to ligand (1:2 and 1:4) in solution, the difficulties still encountered in the identification of "metastable" complex are not early understood. ${ }^{27}$

\section{Acknowledgments}

We are grateful to the Pars Material Research and Testing (PMRT) for valuable technical assistance.

\section{References}

1. Martelli, P. B.; Reis, B. F.; Korn, M.; Rufini, I. A.; J. Braz. Chem. Soc. 1997, 8, 479.

2. Jung, M. J.; Venkateswaran, P.; Lee, Y. S.; J. Ind. Eng. Chem. (Seoul, Repub. Korea) 2008, 14, 110.

3. Marczenko, Z.; Balcerzac, M.; Separation, Preconcentration and Spectrophotometry in Inorganic Analysis, Elsevier:London, 2000; p. 290.

4. Booth, E.; Strickland, J. D. H.; J. Am. Chem. Soc. 1953, 75, 3017.

5. Yonezawa, C.; Sagawa, T.; Hoshi, M.; Tachikawa. E.; J. Radioanal. Chem. 1983, 8, 7.

6. Shemirani, F.; Zamani M.; Jamali, M. R.; Iran. J. Chem. Chem. Eng. 2003, 22, 55.

7. Gazda, D. B.; Fritz, J. S.; Porter, M. D.; Anal. Chim. Acta 2004, 508, 53.

8. Ali, A.; Ye, Y.; Xu, G.; Yin, X.; Zhang, T.; Microchem. J. 1999, 63,365 .

9. Marczenko, Z.; Crit. Rev. Anal. Chem. 1981, 11, 195.

10. Marczenko, Z.; Jaroz, M.; Analyst 1981, 106, 751.

11. Kalinowski, K.; Marczenko, Z.; Mikrochim. Acta 1985, 85,167.

12. Marczenko, Z.; Jankowski, K.; Anal. Chim. Acta 1985, 176, 185.

13. Kalinowski, K.; Marczenko, Z.; Anal. Chim. Acta 1986, 186, 331.

14. Mathew, L.; Reddy, M. L. P.; Ramamohan, M. L. P.; Prasad, M. L. P.; Lyer, C. S. P.; Damodaran, A. D.; Mikrochim. Acta 1997, 127, 125.

15. Bhagavathy, V.; Prasada Rao, T.; Damodaran, A. D.; Anal. Chim. Acta 1993, 280, 169.

16. Chamsaz, M.; Arbab-Zavar, M. H.; Hosseini, M. S.; Anal. Lett. 2000, 33, 1625. 
17. Chamsaz, M.; Hosseini, M.S.; Arbab-Zavar, M. H.; Chem. Anal. 2004, 49, 241.

18. Hosseini, M. S.; Nasseri, Y.; Anal. Sci. 2003, 19, 1505.

19. Hosseini, M. S.; Hashemi-Moghaddam, H.; Anal. Sci. 2004, 20, 1449.

20. Hosseini, M. S.; Hashemi-Moghaddam H.; Talanta 2005, 67, 555.

21. Hosseini, M. S.; Hashemi-Moghaddam H.; Bull. Korean Chem. Soc. 2005, 26, 1529.

22. Hosseini, M. S.; Hashemi-Moghaddam, H.; KardanMoghaddam, G.; Ann. Chim. (Rome, Italy) 2007, 97, 17.
23. Shabazi, Z.; Dadfarnia, S.; Shabani, A. M. H.; Jafari, A. A.; J. Anal. Chem. 2008, 63, 446.

24. Pourreza, N.; Parham H.; Mirzavand P.; J. Chin. Chem. Soc. 2009, 56, 785.

25. Rudolf, B.; A Handbook of Decomposition Methods in Analytical Chemistry, International Textbook Company Ltd., 1979. ch. 4.

26. Irving, H. M. N. H.; Pure Appl. Chem. 1978, 50, 1129.

27. Sivaramakrishna, A.; Rao, V. J.; Muralikrishna, U.; Moss, J. R.; Transition Met. Chem. (Dordrecht, Neth.) 2008, 33,475.

Submitted: August 18, 2010 Published online: February 15, 2011 


\title{
Identification of $(1 R, 2 S)$-Grandisal and $(1 R, 2 S)$-Grandisol in Pissodes castaneus Male-Produced Volatiles: Evidence of a Sex Pheromone
}

\author{
Francisco A. Marques, ${ }^{*, a}$ Scheila R. M. Zaleski, ${ }^{b}$ Sonia M. N. Lazzari, ${ }^{b}$ \\ Gustavo Frensch, ${ }^{a}$ Grece A. Senhorini, ${ }^{a}$ Beatriz H. L. N. S. Maia, ${ }^{a}$ \\ Armin Tröger, ${ }^{c}$ Wittko Francke, ${ }^{c}$ Edson T. Iede ${ }^{d}$ and Kenji Mori ${ }^{e}$
}

${ }^{a}$ Departamento de Química, Universidade Federal do Paraná, P.O. Box 19081, $81531-990$ Curitiba-PR, Brazil

${ }^{b}$ Departamento de Zoologia, Universidade Federal do Paraná, P.O. Box 19020, 81531-980 Curitiba-PR, Brazil 'Institute of Organic Chemistry, University of Hamburg, Martin-Luther-King-Platz 6, D-20146, Hamburg, Germany

${ }^{d}$ Laboratório de Entomologia, Empresa Brasileira de Pesquisa Agropecuária, P.O.Box 319, 83411-000, Colombo-PR, Brazil

${ }^{e}$ Photosensitive Materials Research Center, Toyo Gosei Co., Ltd., 4-2-1 Wakahagi, Inzai-shi, Chiba 270-1609, Japan

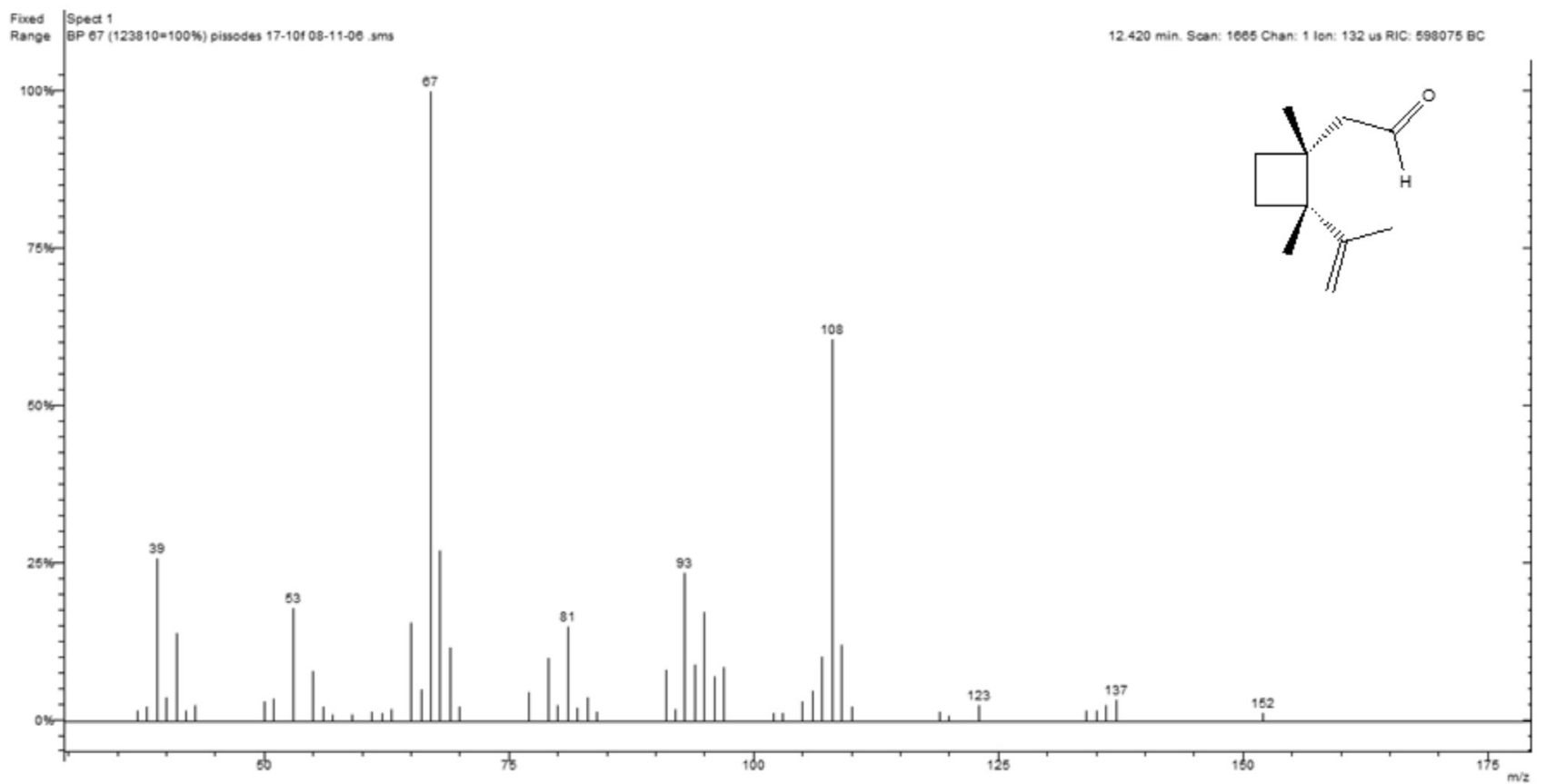

Figure S1. Mass spectrum of grandisal. 


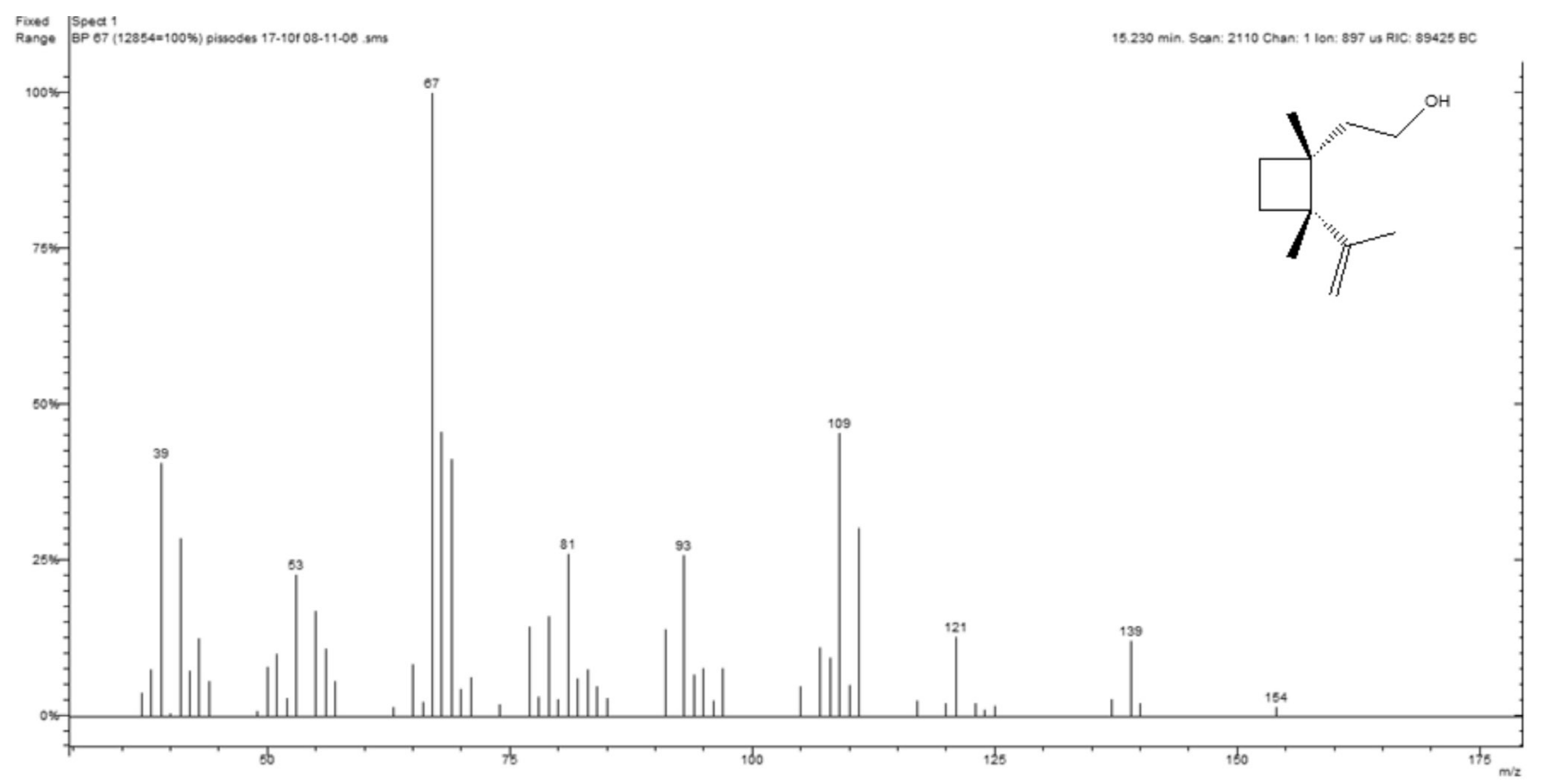

Figure S2. Mass spectrum of grandisol. 